\title{
Nutritional status of Haitian children, 1978-1995: Deleterious consequences of political instability and international sanctions
}

\author{
Menno Mulder-Sibanda ${ }^{1}$
}

ABSTRACT Results from three national surveys in Haiti suggest that the prevalence of stunting, underweight, and wasting in children fell considerably between 1978 and 1990. In the following four years, rates of stunting and underweight levelled off, while that of wasting nearly doubled. Child nutrition deteriorated dramatically during a period of intense political crisis and international sanctions that included a strictly enforced trade embargo. Human welfare should be monitored whenever international sanctions are imposed to regulate a country's behavior.

It is widely accepted that measures of nutritional status provide useful insights into the health, social, and food status of populations $(1,2)$. Trends in child nutritional status accurately and objectively reflect changes in standards of living (3).

The past two decades have witnessed great changes in basic indices of social development in Haiti. Between 1976 and 1980, gross domestic product (GDP) grew more than $4 \%$ annually. There followed nearly a decade of economic stagnation, related partly to the world recession. From 1991-1994, political instability and an international trade embargo took a toll on GDP growth, causing it to decline dramatically (4). Per capita income dropped

\footnotetext{
1 Former nutrition consultant, Pan American Health Organization, Port-au-Prince, Haiti. Mailing address: B.P. 443, Abidjan 04, Côte d'Ivoire.
}

while prices of basic commodities, including food, rose sharply (5).

The percentage of Haitians receiving public services increased throughout most of the 1980s, but coverage for most services declined substantially after 1989 (6). Physical access to health services worsened owing to decay of physical infrastructure, high cost or interruption of transportation, lack of supplies and drugs, and deterioration of communications and supervision. An unusually long and deadly measles epidemic, directly attributable to a breakdown of immunization coverage, ravaged Haitian children from mid-1991 to the end of 1993. Outbreaks of other diseases during 19911994, including rabies, anthrax, and meningitis, further testify to the poor state of health services.

Large population movements occurred during these decades. The population of Port-au-Prince doubled between 1982 and 1988, and that city is now home to almost two million people, or an estimated $28 \%$ of all Haitians (7). However, the urbanizing trend reversed in 1991, when many people left the cities in response to political repression and economic insecurity. Significant internal migration has taken place since 1991, although its magnitude and overall direction cannot be quantified (8).

The impacts that these changes in social structures and the living conditions of ordinary Haitians have had on child care, children's health, and nutrition are largely unknown. The present study aims to enhance understanding through an examination of the nutritional status of Haitian children from 1978 through 1995.

National surveys collecting crosssectional data on the prevalence of wasting (low weight-for-height [WH]), stunting (low height-for-age [HA]), and underweight (low weight-for-age [WA]) were carried out between June 
and September 1978, in September 1990, and from July 1994 to January 1995. Details of the survey methodologies have been published (7, 9-11). The first two surveys utilized two-stage, stratified cluster sampling. The 1978 survey is based on six strata, the 1990 on only two. In both cases, the second stage involved a population proportional selection of 30 clusters in each of the strata, each cluster with a minimum of 30 children. The 1994/95 survey utilized population proportional sampling of households from 172 clusters which were randomly selected from three different strata-metropolitan, urban, and rural. Weighting factors for population sizes were applied to results from all three surveys to enhance prevalence estimates for the country as a whole.

The 1978 and 1990 surveys included children from 3-59 months of age, while the 1994/95 survey took all children under 5 years of age. Therefore, children from 0-5 months are excluded from this review. The numbers of children aged 6-59 months were 5004 (1978), 1718 (1990), and 2502 (1994). Age and sex distributions were very similar in all three surveys.

In the 1978 survey, the prevalence of malnutrition was estimated by calculating the proportion of children with an anthropometric index below a threshold percentage of the reference population's median $(80 \%$ for WH, $75 \%$ for WA, $90 \%$ for HA). Prevalence estimates in the 1994/95 survey were obtained by calculating the proportion of children with index $Z$ scores $<-2$. The 1990 survey data analysis applied both methods. All three surveys used the National Center for Health Statistics references values (12).

Estimates of the national prevalence of childhood malnutrition by age group according to the surveys are presented in Tables 1-3.

A $12 \%$ reduction in the prevalence of stunting occurred from 1978 to 1990 (Table 1). Since HA is a cumulative indicator, changes were concentrated in the older age groups. Between 1990 and 1994/95, the prevalence of growth failure declined a mere $4 \%$.

The proportion of underweight children fell by a remarkable $33 \%$ between
TABLE 1. Prevalence of stunting by height-for-age in 1978, 1990, and 1994-1995 by age group and the percentage change over two intervals ${ }^{a}$

\begin{tabular}{crrrrrrrr}
\hline & \multicolumn{3}{c}{ Height/Age<90\% } & & \multicolumn{3}{c}{ Height/Age $<-2$ Z scores } \\
\cline { 2 - 3 } Age (months) & 1978 & 1990 & $\%$ & & 1990 & $1994-1995$ & $\%$ \\
\hline $6-11$ & 5.7 & 7.4 & 29.8 & & 16.4 & 14.9 & -9.2 \\
$12-23$ & 19.2 & 20.1 & 4.7 & & 35.3 & 36.7 & 4.0 \\
$24-35$ & 35.2 & 25.7 & -27.0 & & 41.9 & 36.7 & -12.4 \\
$36-47$ & 37.1 & 25.6 & -31.0 & & 39.7 & 38.6 & -2.8 \\
$48-59$ & 42.0 & 29.5 & -29.8 & & 41.8 & 40.7 & -2.6 \\
Average & & & -12.1 & & & & -4.1 \\
\hline
\end{tabular}

a Based on data in ref. 7, 8, and 10. the first two surveys. Thereafter, it rebounded 6\% between 1990-1994/95 (Table 2). As attained height is directly related to attained weight, Tables 1 and 2 to some extent demonstrate the same phenomenon.

The proportion of children with wasting was 48\% lower in 1990 compared to 1978 (Table 3). All age groups shared in this improvement. In the ensuing 4 years, the prevalence of wast- ing almost doubled. Figures 1 and 2 illustrate the magnitude of changes in wasting prevalence.

These results of the national random surveys indicate that substantial improvements in the nutritional status of Haitian children aged under 5 years occurred between 1978 and 1990, and that considerable deterioration took place in the following 4 years. Before drawing conclusions, however, it is
TABLE 2. Prevalence of underweight children by weight-for-age in 1978, 1990, and 1994-1995 by age group and the percentage change over two intervals ${ }^{a}$

\begin{tabular}{cccccccr}
\hline & \multicolumn{3}{c}{ Weight/Age<75\% } & & \multicolumn{3}{c}{ Weight/Age<-2 Z scores } \\
\cline { 2 - 3 } Age (months) & 1978 & 1990 & $\%$ & & 1990 & $1994-1995$ & $\%$ \\
\hline $6-11$ & 15.2 & 10.4 & -31.6 & & 16.0 & 18.9 & 18.1 \\
$12-23$ & 28.8 & 21.3 & -26.0 & & 32.6 & 32.7 & 0.3 \\
$24-35$ & 31.7 & 19.5 & -38.5 & & 32.3 & 33.4 & 3.4 \\
$36-47$ & 30.0 & 20.0 & -33.3 & & 27.4 & 29.4 & 7.3 \\
48-59 & 35.2 & 23.1 & -34.4 & & 30.4 & 32.1 & 5.6 \\
Average & & & -32.6 & & & & +6.0 \\
\hline
\end{tabular}

Based on data in ref. 7,8 , and 10.

TABLE 3. Prevalence of wasting by weight-for-height in 1978, 1990, and 1994-1995 by age group and the percentage change over two intervals ${ }^{a}$

\begin{tabular}{ccccccrrr}
\hline & \multicolumn{3}{c}{ Weight/Height<80\% } & & \multicolumn{3}{c}{ Weight/Height <-2 Z scores } \\
\cline { 2 - 3 } Age (months) & 1978 & 1990 & $\%$ & & 1990 & $1994-1995$ & $\%$ \\
\hline $6-11$ & 5.1 & 1.7 & -66.7 & & 2.0 & 8.4 & 320.0 \\
$12-23$ & 9.8 & 6.2 & -36.7 & & 9.8 & 13.8 & 40.8 \\
$24-35$ & 7.4 & 3.1 & -58.4 & & 3.8 & 8.4 & 121.1 \\
$36-47$ & 3.7 & 2.3 & -37.8 & & 4.2 & 5.5 & 31.0 \\
$48-59$ & 3.8 & 2.1 & -44.7 & & 3.2 & 4.8 & 50.0 \\
Average & & & -47.5 & & & & +96.5 \\
\hline
\end{tabular}

a Based on data in ref. 7,8 , and 10. 
FIGURE 1. Prevalence of wasting by weight-for-height $<80 \%$ in 1978 and 1990

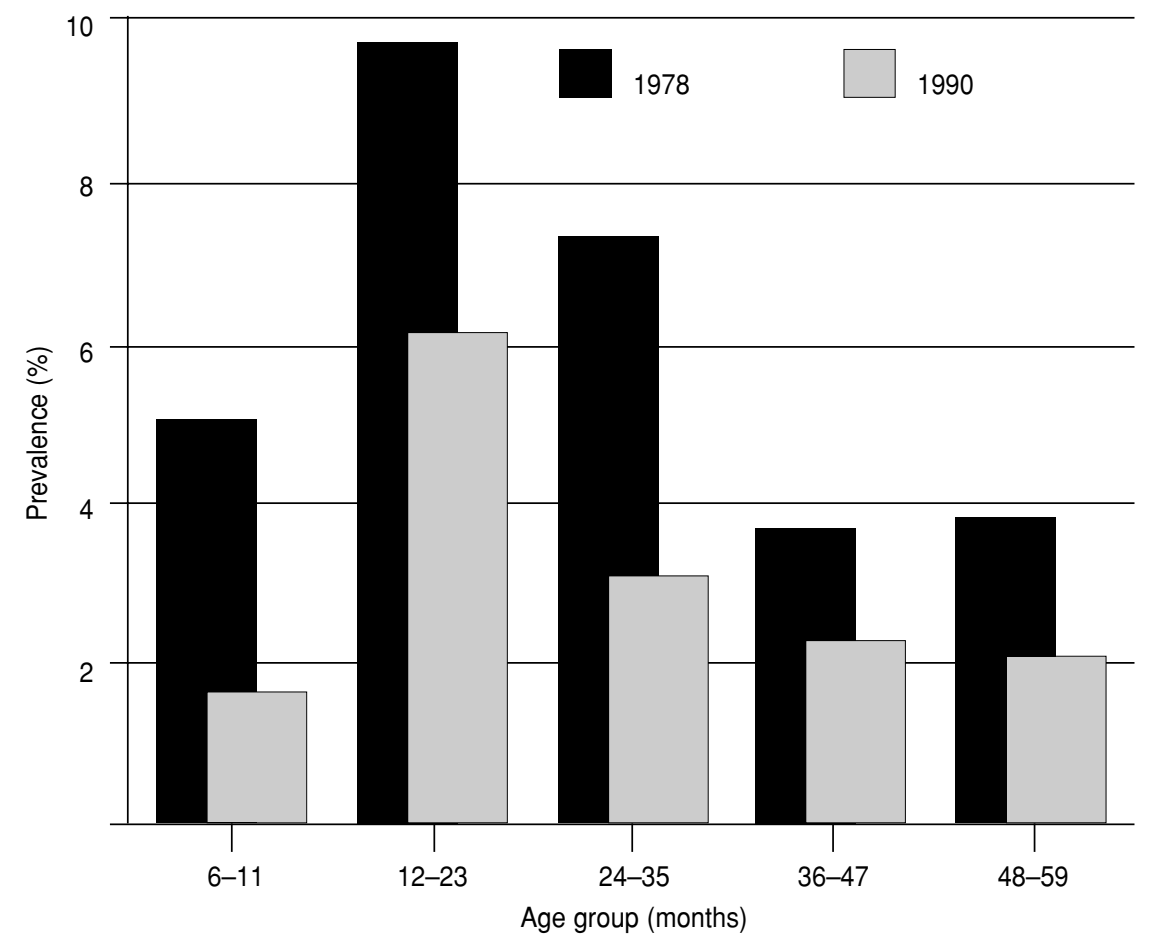

FIGURE 2. Prevalence of wasting by weight-for-height $<-2$ Z scores in 1990 and 1994-1995

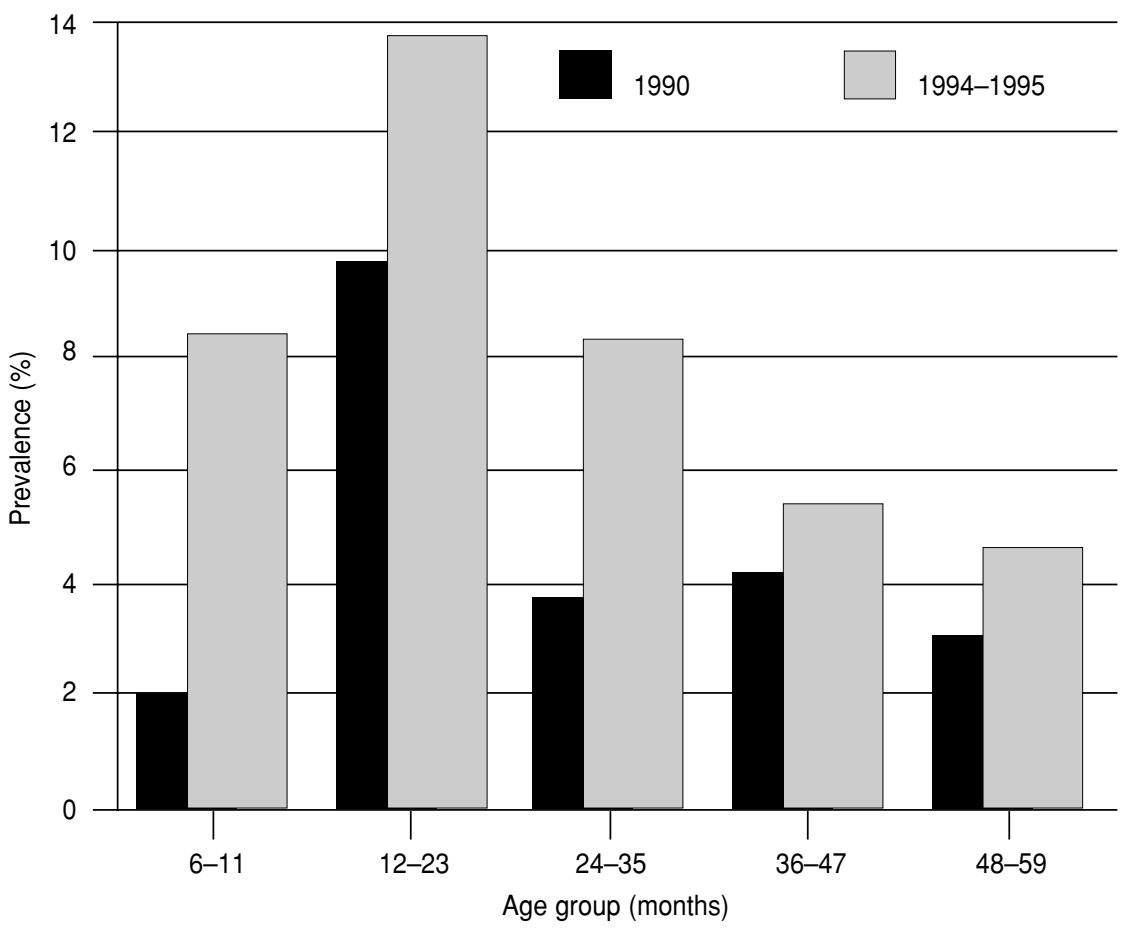

necessary to consider whether the observed trends are only apparent, due to differences in survey methodologies.

Provincial towns were excluded from the 1978 sampling frame but included in the 1990 survey. Malnutrition and stunting are generally more prevalent in rural than in urban areas. Therefore, some of the 1978 advantage in prevalence rates may be artifactual. The size of such artifact would be limited, however, since with the sole exception of the Port-au-Prince metropolitan area (which was included in both surveys), most provincial towns have a predominantly rural character.

The 1994/95 survey followed a sampling methodology distinct from the others. Theoretically, weighting of results at the national level should compensate for the sampling difference. Nonetheless, there is a possible problem with respect to the pertinence of the population estimates which were used to establish the prevalence rates. These were based on projections of the 1982 census and did not take into account the major population distribution changes in the wake of the political crisis.

Seasonal effects may also have influenced the outcomes of these surveys. Seasonality in incomes due to cyclical labor demand, and in food prices due to varying availability, may result in transitory food insecurity and fluctuations in nutritional status. Although Haiti has various microclimates, the months of June to August are known throughout the country as "the hungry season." This period coincides with a major peak in diarrheal diseases. October to January are months of relative plenty, when the largest amounts of food are available and prices are at their lowest (13). The 1990 data, collected in the midst of a hungry season, may have resulted in inflated estimates of malnutrition in comparison to the 1994/95 results. In other words, the deterioration noted between 1990 and 1994/95 may actually have been an underestimation.

Child mortality at ages 1-4 declined from $77 / 1000$ in $1975-1979$ to 63/ 1000 in 1980-1984 and 56/1000 in 1985-1989 (7); an impressive 27\% reduction over a 10-year period. The nu- 
tritional deterioration observed in the 4 years following 1990 was accompanied by a $9 \%$ increase, to 61 in 1000 , in mortality among young children (7). These changes in child mortality correspond to the trends in malnutrition, supporting their credibility.

Haitian children's improvements in nutritional status during the 1980s coincided with similar improvements in most parts of the world. Between 1975 and 1990, the total prevalence of underweight children (WA $<-2$ Z scores) aged 0-4 years in developing countries is estimated to have fallen by $18 \%$. In Central America and the Caribbean, the drop was $21 \%$ (14). Undoubtedly, Haiti entered this period with much higher levels of malnutrition than most neighboring countries. Therefore, it is lamentable that the gains made in the eighties were lost within a period of only 4 years.

The 1990 and 1994/95 surveys were conducted shortly before and at the end of the 1991-1994 political crisis, which was characterized by lack of governance, economic mismanagement, collapse of public services, and political violence. The impact of the crisis on human welfare was exacerbated by international sanctions which were imposed throughout almost the entire period and became extremely stringent in 1993-1994. Methodological difficulties preclude confident estimation of the proportion of the deterioration in Haitian children's nutrition due to the political crisis, and that due to the embargo per se $(8,15)$.

In recent years, the United Nations has imposed economic sanctions on Iraq, Haiti, Libya, and the former $\mathrm{Yu}$ goslavia, among other countries. Yet, little is known about the extent to which such actions achieve the desired effects or implicate undesired ones. The apparently rising popularity of economic sanctions as an instrument of foreign policy calls for more rigorous attempts to monitor the human situation of affected populations. As this paper illustrates, such information is necessary for general policy recommendations to mitigate the human damage that may be caused by external political intervention.

\section{REFERENCES}

1. Dowler EA, Payne PR, Seo YO, Thomson AM, Wheeler EF. Nutritional status indicators: Interpretation and policy making role. Food Policy 1982;May:99-112.

2. De Onis M, Monteiro C, Akré J, Clugston G. The worldwide magnitude of protein-energy malnutrition: An overview from the $\mathrm{WHO}$ Global Database on Child Growth. Bull World Health Organ 1993;71:703-712.

3. Mason JB, Habicht JP, Tabatabai H, Valverde V. Nutritional surveillance. Geneva: World Health Organization; 1984.

4. The Economist Intelligence Unit. Dominican Republic, Haiti, Puerto Rico Country Profile 1992-93: Annual survey of political and economic background. London: The Economist Intelligence Unit; 1992.

5. United States Agency for International Development. Haiti: USAID monitoring report. Volumes 4 and 5. Port-au-Prince: USAID; 19941995.

6. Pan American Health Organization. Health situation analysis: Haiti 1993. Port-au-Prince: PAHO; 1993.
7. Cayemittes $M$, Rival $A$, Barrère B, Lerebours G, Amédée Gédéon M. Enquête Mortalité Morbidité et Utilisation des Services (EMMUSII), Haïti, 1994/95. Calverton, Maryland: Macro International, Inc.; 1995.

8. Harvard Center for Population and Development Studies. Sanctions in Haiti: Crisis in humanitarian action. Cambridge, Massachusetts: Harvard School of Pubic Health; 1993.

9. Bureau of Nutrition of the Department of Public Health and Population. Haiti nutrition status survey 1978. Washington, DC: United States Agency for International Development; 1979.

10. Graitcer PL, Gedeon MA, De Beausset I, Duckett EM. Haiti nutrition status survey, 1978. Bull World Health Organ 1980;58:757-765.

11. Centers for Disease Control, Child Health Institute, Ministry of Public Health and Population, Pan American Health Organization, United States Agency for International Development. Haiti's nutrition situation in 1990: A report based on anthropometric data of the $1991 \mathrm{nu}$ trition surveys. Port-au-Prince: PAHO; 1993.
12. WHO Working Group. Use and interpretation of anthropometric indicators of nutritional status. Bull World Health Organ 1986;64: 929-941.

13. Mulder-Sibanda M. Food, health and care in Haiti: A nutrition situation analysis. Int Child Health 1996;7(2):5-30.

14. United Nations Administrative Committee on Coordination Subcommittee on Nutrition. Second report on the world nutrition situation. Volume I: Global and regional results. Geneva: United Nations; 1992.

15. Garfield R. The impact of the economic crisis and the US embargo on health in Cuba. Am J Public Health 1997;87:15.

Manuscript received on 7 January 1997. Revised version accepted for publication on 28 July 1998.
RESUMEN Estado nutricional de niños
haitianos, 1978-1995:
consecuencias adversas de la
inestabilidad política y de las
sanciones internacionales
Según los resultados de tres encuestas nacionales en Haití, la prevalencia del retraso del crecimiento, la insuficiencia ponderal y la emaciación en niños se redujeron notablemente entre 1978 y 1990. En los años posteriores, las tasas de retraso del crecimiento y de insuficiencia ponderal se nivelaron, mientras que la tasa de emaciación casi se duplicó. La nutrición de los niños se deterioró marcadamente durante un período de crisis política intensa y de sanciones internacionales, que incluyeron un bloqueo económico riguroso. Es necesario vigilar el bienestar de los seres humanos cuando se imponen sanciones internacionales para controlar las acciones de un país. 